\title{
骨賄移植予定患者の歯科治療に関する臨床的検討
}

一抜菌後合併症について—

\author{
後藤康之·竹内学・小関健司 ·藤内 祝* ${ }^{*}$ 上田 実 ${ }^{*}$
}

\section{Clinical study of dental management in patients undergoing bone marrow transplantation-Complications following tooth extraction-}

\author{
Yasuyuki Goto $\cdot$ Manabu TakeuchI $\cdot$ Kenji Ozeki $\cdot$ Iwai TohnaI* $\cdot$ Minoru Ueda*
}

\begin{abstract}
Of 78 patients examined at the department of Oral and Maxillofacial Surgery, Nagoya Daini Red Cross Hospital for pre-BMT (bone marrow transplantation) dental evaluation between October 1987 and December 1993, 28 who underwent tooth extraction were studied with regard to complications. There were 16 men and 12 women. The mean age of patients was 39.6 years (range, 9 to 50 years). The mean period from dental screening to BMT was 34.1 days, and that from the latest tooth extraction to BMT was 29.4 days. A total of 82 teeth were extracted.

Postoperative complications included dry socket ( $7 / 82$ teeth), postoperative bleeding ( 8 $/ 82$ teeth), and postoperative fever $(4 / 28$ patients $)$. Fever was present in one patient during BMT because of an extraction-socket infection. Tooth extraction did not influence the outcome of any BMT recipient.

In conclusion, adequate treatment and follow-up periods are considered nessesary in patients scheduled to undergo bone marrow transplantation who require tooth extraction.
\end{abstract}

Key words: bone marrow transplantation (骨髄移植), dental management (歯科治療), tooth extraction (拔歯)

\section{緒言}

骨䯣移植 (以下 BMT と略す) 患者は前処置による 骨髄抑制および移植後の免疫抑制のため重症感染症を 生じやすく, その子防のため移植前に口腔内の感染源 を除去する必要がある ${ }^{1 \sim 3)}$. 感染源となり得る歯に対し ては抜歯が第 1 選択とされるが, 患者の全身状態から一 般患者とは異なった治療方針を要求される．そこで本研 究では, BMT 予定患者の抜歯に対する治療指針の作成 を目的として BMT 前に抜歯を行った症例の術後合併症 を調査し, 抜歯がBMTに及ほ影響について検討した。

\section{対象および調查項目}

対象症例は 1987 年 10 月〜 1993 年 12 月の間に BMT

名古屋第一赤十字病院歯科口腔外科

(主任 : 竹内 学部長)

*名古屋大学医学部口腔外科学講座

(主任：上田 実教授)

Department of Oral and Maxillofacial Surgery,

Nagoya Daini Red Cross Hospital (Chief:

Manabu Takeuchi)

*Department of Oral Surgery, Nagoya University School of Medicine (Chief: Prof. Minoru Ueda)

受付日：平成 7 年 10 月 23 日
前の口腔診査にて名古屋第二赤十字病院歯科口腔外科 を受診した 78 人の内, 抜歯を行った 28 人とした. 年 齢は平均 36.9 歳 ( 9 - 50 歳) で, 性別は男性 16 人, 女 性 12 人であった. 原疾患名は急性骨骾性白血病 (AML) 3 人, 急性リンパ性白血病 (ALL) 3 人, 慢性骨髄性白 血病 (CML) 15 人, 骨髄異形性症候群 (MDS) 1 人, 再生不良性貧血（AA） 4 人, 悪性リンパ腫（NHL）2 人であった（表 1 ).

検討項目は, 歯科依頼および最終抜歯から BMT ま での日数, 術前検査所見, 他科の治療, 抜歯部位およ び抜歯後合併症, 抜歯による BMT 後の合併症とした。

\section{結果}

1.歯科依頼および最終抜菌から BMT までの日数

歯科依頼から BMT までの日数は, 平均 34.1 日で, BMT の 3 週間以上前に 23 症例 (82.1\%) が歯科受診 した. 最終抜歯から BMT までの日数は, 平均 29.4 日 で, BMT の 3 週間以上前に 22 症例 (78.6\%) が最終 抜歯を終了した（表 2 )。

2. 術前検查所見 抜歯前の血液検查所見にて, 白 血球数 (WBC) では 11 症例は低值 $(4000 / \mu \mathrm{l}$ 以下), 11 症例は高值 $(10000 / \mu 1$ 以上) を示した。血色素量 
表 1 症例一覧 (年齢・性別 - 原疾患名, 術前検查所見, 他科の治療, 抜歯部位・抜歯後合併症)

\begin{tabular}{|c|c|c|c|c|c|c|c|c|}
\hline \multirow[b]{2}{*}{ 症例 } & \multirow[b]{2}{*}{ 年齢 } & \multirow[b]{2}{*}{ 性別 } & \multirow[b]{2}{*}{ 原疾患名 } & \multicolumn{3}{|c|}{ 術前検查所見 } & \multirow{2}{*}{$\begin{array}{l}\text { 他科の治療 } \\
\text { (投薬内容) }\end{array}$} & \multirow{2}{*}{$\begin{array}{c}\text { 抜歯部位・抜歯後合併症 } \\
(\bigcirc: \text { ドライソケット } \\
\triangle: \text { : 後出血, } \square: \text { 発熱) }\end{array}$} \\
\hline & & & & $\left(\begin{array}{l}\mathrm{WBC} \\
(/ \mu 1)\end{array}\right.$ & $\begin{array}{c}\mathrm{Hb} \\
(\mathrm{g} / \mathrm{dl})\end{array}$ & $\stackrel{\mathrm{Plt}}{\left(10^{4} / \mu 1\right)}$ & & \\
\hline 1. & 13 & 女 & AML & 6400 & 13.5 & 20.6 & 無 & \begin{tabular}{l|l}
$E$ & \\
$E$
\end{tabular} \\
\hline 2. & 35 & 女 & AML & 3500 & 11.2 & 14.4 & 慢性扁桃炎にて手術 & \begin{tabular}{l|l}
3 & \\
5
\end{tabular} \\
\hline 3. & 45 & 男 & $\mathrm{AML}$ & 15200 & 6.4 & 5.9 & 無 & $\frac{8}{8(6)}$ \\
\hline 4. & 9 & 女 & ALL & 3900 & 9.4 & 76.9 & 無 & \begin{tabular}{l|l}
$\mathrm{B}$ & $\mathrm{B}$ \\
\end{tabular} \\
\hline 5. & 36 & 男 & ALL & 5200 & 14.6 & 14.4 & 肛門周囲腫瘍 (抗菌剂) & (8) \\
\hline 6. & 50 & 男 & ALL & 3200 & 10.4 & 38.7 & 慢性扁桃炎にて手術 & \begin{tabular}{l|l}
755 & \multicolumn{2}{|c}{4} \\
75 & $23 \quad 68$
\end{tabular} \\
\hline 7. & 29 & 女 & CML & 121400 & 11.7 & 48.1 & \begin{tabular}{|c|l} 
無 \\
\end{tabular} & \begin{tabular}{l|l}
4 \\
\end{tabular} \\
\hline 8. & 31 & 女 & CML & 15300 & 12.8 & 80.5 & 無 & 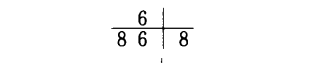 \\
\hline 9. & 34 & 女 & CML & 75300 & 11.0 & 92.8 & 無 & $\sqrt{68}$ \\
\hline 10. & 35 & 男 & CML & 4100 & 9.6 & 7.2 & 無 & $\begin{array}{ll}1 \\
8\end{array}$ \\
\hline 11. & 37 & 女 & CML & 182600 & 8.5 & 35.8 & 無 & $-\frac{1}{4 \sqrt{5}}$ \\
\hline 12. & 38 & 男 & CML & 14900 & 15.2 & 58.7 & 慢性扁桃炎 & 8t \\
\hline 13. & 39 & 男 & CML & 8000 & 13.9 & 23.0 & 無 & -6 \\
\hline 14. & 39 & 女 & CML & 11800 & 6.7 & 4.5 & 無 & \begin{tabular}{ll|l}
6054 & 1567 \\
76 & 21 & 7
\end{tabular} \\
\hline 15. & 40 & 男 & CML & 55700 & 9.2 & 96.3 & 慢性扁桃炎 & \begin{tabular}{l|l}
8 & 8 \\
\end{tabular} \\
\hline 16. & 40 & 女 & CML & 5300 & 11.4 & 37.9 & 無 & \begin{tabular}{l|l}
7654 & 67 \\
76 & 6
\end{tabular} \\
\hline 17. & 42 & 男 & CML & 7200 & 13.3 & 14.7 & 胃潰瘍（H 2 拮抗薬） & \begin{tabular}{l|l} 
& 6 \\
7 & $7(8)$
\end{tabular} \\
\hline 18. & 42 & 女 & CML & 3700 & 7.7 & 75.2 & 痔疾 & \begin{tabular}{l|l} 
& 4 \\
2 & 2
\end{tabular} \\
\hline 19. & 44 & 女 & CML & 64400 & 12.5 & 41.0 & 痔疾 & \begin{tabular}{l|rl}
7 & 567 \\
7 & 7
\end{tabular} \\
\hline 20. & 46 & 男 & CML & 29300 & 14.8 & 30.8 & 慢性扁桃炎 & 18 \\
\hline 21. & 47 & 男 & CML & 38400 & 15.3 & 50.6 & 肺炎（抗菌剤） & 18 \\
\hline 22. & 33 & 男 & MDS & 1600 & 5.7 & 8.3 & 痔疾 & \begin{tabular}{|l|l}
8 & 8 \\
\end{tabular} \\
\hline 23. & 30 & 男 & $\mathrm{AA}$ & 1500 & 7.5 & $2.1 \rightarrow 6.9$ & 無 & (6) \\
\hline 24 & 34 & 女 & $\mathrm{AA}$ & 1200 & 5.9 & $0.5 \rightarrow 7.5$ & 無 & से \\
\hline 25. & 37 & 男 & $\mathrm{AA}$ & 2500 & 5.0 & $2.6 \rightarrow 7.4$ & 無 & \begin{tabular}{l|l}
8 \\
77
\end{tabular} \\
\hline 26. & 46 & 男 & $\mathrm{AA}$ & 1700 & 6.6 & $0.8 \rightarrow 5.0$ & 痔疾 & \begin{tabular}{l|l}
7 & 7 \\
7 &
\end{tabular} \\
\hline 27. & 39 & 男 & NHL & 3500 & 13.7 & 21.0 & 無 & $\begin{array}{l}8 \\
\end{array}$ \\
\hline 28. & 44 & 男 & NHL & 1800 & 9.6 & 16.0 & 足背部壊㾝 (外用薬) & $\begin{array}{l}(4) \\
\end{array}$ \\
\hline
\end{tabular}

( $\mathrm{Hb})$ では 13 症例が $10 \mathrm{~g} / \mathrm{dl}$ 以下であった. 血小板数 (Plt) では 8 症例は低值 $\left(10 \times 10^{4} / \mu 1\right.$ 以下), 9 症例 は高値 $\left(40 \times 10^{4} / \mu 1\right.$ 以上)を示した（表 1$)$.

3. 他科の治療 他科による BMT 前の全身検索に て 13 症例が感染巣の指摘を受けた。慢性扁桃炎は 5 症例あり，その内 2 症例は扁桃摘出術を受けた。痔疾 は 4 症例認めたが, 治療を必要としなかった。他の 4 症例は肛門周囲膿瘍, 胃潰瘍, 肺炎, 足背部壊疸にて それぞれ投薬治療を受けた。すべての症例でこれらの
病変は BMT に支障はないと診断された（表 1 ）。

4. 拢歯部位および抜歯後合併症 抜歯部位は上顎 37 歯, 下顎 45 歯でその内上顎大臼歯と智歯は 21 歯, 下顎 大臼歯と智歯は 33 蒾であった(表 1 ).

抜歯時白血球数に異常 $(4000 / \mu 1$ 以下および 10000 $/ \mu 1$ 以上）を示した症例には，抗菌剤の子防投与を 行い, $\mathrm{AA}$ にて血小板数が少ない 4 症例は血小板輸血 を行なった後, 抜歯した。また，全症例に対し術後抗 菌剂投与を行った。 
表 2 歯科依頼および最終抜歯から BMT までの日数

\begin{tabular}{cc||cc}
\hline $\begin{array}{c}\text { 歯科依頼から } \\
\text { BMTまでの日数 }\end{array}$ & 症例数 $(\%)$ & $\begin{array}{c}\text { 最終抜歯加 } \\
\text { BMTまでの日数 }\end{array}$ & 症例数 $(\%)$ \\
\hline $0 \sim 1$ 週前 & $0(0)$ & $0 \sim 1$ 週前 & $0(0)$ \\
$1 \sim 2$ 週前 & $3(10.7)$ & $1 \sim 2$ 週前 & $3(10.7)$ \\
$2 \sim 3$ 週前 & $2(7.2)$ & $2 \sim 3$ 週前 & $3(10.7)$ \\
$3 \sim 4$ 週前 & $9(32.1)$ & $3 \sim 4$ 週前 & $11(39.3)$ \\
$4 \sim 5$ 週前 & $7(25.0)$ & $4 \sim 5$ 週前 & $6(21.4)$ \\
5 週前以上 & $7(25.0)$ & 5 週前以上 & $5(17.9)$ \\
\hline 平均 34.1 日 & $28(100)$ & 平均 29.4 日 & $28(100)$ \\
\hline
\end{tabular}

抜歯後合併症は, ドライソケット 6 症例 7 歯, 後出血 7 症例 8 歯, 発熱 $\left(37.5^{\circ} \mathrm{C}\right.$ 以上) 4 症例を認めた（表 1$)$.

その治療として, ドライソケットは抜歯窩を洗浄後, 抗菌作用と鎮痛作用を有する軟亮ガーゼを挿入するこ とにより7-14 日で治癒した，後出血はガーゼによる 再圧迫，止血片投与，縫合等を行い，翌日までには全 ての症例で止血可能であった。発熱は解熱剂と抗菌剤 投与にて早期（1-3日）に改善した.

5. 拢歯による BMT 後の合併症 BMT 18 日前に 6 を抜歯した 1 例（症例 3 ）は, BMT 後抜歯窩の違 和感と高熱持続のため, 抜歯窩の細菌培養と血液培養 したところ同じ細菌（Staphylococcus haemolitics） を認めた。他に明らかな感染巣は認められなかった。 治療は抗菌剤の静脈内投与 (FOMX + AMZ)にて 8 日後に改善した. 他には抜歯により重篤な合併症を引 き起こした症例はなかった。

\section{考察}

BMT 予定患者は移植前に化学療法を行っているこ とが多く，骨䯣抑制による沉血球隇少のため易感染性, 易出血性, 創傷治癒遅延を伴い2), 抜歯後合併症が起 こりやすい事が推測される. 今回われわれの検討した 症例では, 抜歯前の術前検查にて汎血球減少または骨 髄に過形成を多く認め, 抜歯後にドライソケット，後 出血, 発熱等の合併症が高頻度に出現した。

ドライソケットは, 抜歯窩の治癒不全と持続する疼 痛を主症状とし, 発生頻度は約 $2 \%$ で, 下顎大臼歯や 智画では約 $7 \%$ と報告されている ${ }^{4)}$. しかし今回の症 例では全体の $8.5 \%$ ( $7 / 82$ 歯), 下顎臼歯部では $15.8 \%$ （6/38 歯）と高頻度に出現した. 年齢は全員 30 歳以上と比較的高年齢であり, 術前に 4 症例は白血 球数の異常，3 症例は筫血を示した。また智歯抜歯を 除く 4 歯は根尖病巣を有していた. よってその原因と しては, 抜歯難易度に加えて患者の年齢，全身状態や 感染巣の存在が関与していると考えられた。

後出血には，抜菌部位特異性は認めなかった。 7 症 例中 4 症例は術前に血小板数低値，2症例は血小板数 高值を示しており，その原因として血小板数減少や凝
集能の機能低下が考えられた.また多数歯同時抜歯後 も 2 症例あり, 術後圧迫止血の不備や局所麻酔薬のリ バウンド効果も考えられた。

発熱の 4 症例中 2 症例は多数歯同時抜歯， 1 症例は 埋伏歯抜歯であった。また 3 症例は術前に白血球数低 值, 貧血を示した.よってその原因としては, 汎血球 隇少による易感染状態に抜歯の侵襲が加わったためと 考えられた。

今回の症例では比較的早期 (平均 34.1 日) に歯科受 診が行われたため, 抜菌後治癒期間（平均 29.4 日）が 確保され，抜歯後合併症が多数発生したにも関わらず, BMT が延期された症例はなかった。しかし BMT 後 敗血症をおこした症例は, 抜歯後ドライソケットにて 治療しており，他に感染巣がないことから，上皮化が 不完全なことによる抜歯窩からの感染が疑われた。

以上より BMT 予定患者の抜歯に関しての治療指針 をまとめると，抜歯前には患者の全身状態を把握し， 抜歯は抜歯窩の上皮化に必要とされる 2 週間の治瘉期 間を確保するため, BMT 前処置の期間も含めると最 低 BMT の 3 週間前までに終了すべきである．さらに 下顎大臼歯, 智歯に関してはドライソケットの可能性 を考慮するとさらに長い治瘉期間を見込んで判断する 必要がある。また多数歯抜歯が必要な際には抜歯順 （下顎 $\rightarrow$ 上顎, 智歯 $\rightarrow$ 大臼歯 $\rightarrow$ 小臼歯 $\rightarrow$ 前歯）も考慮す べきである. 術後管理としては，後出血予防処置（止 血剂投与, 縫合等), 感染予防処置 (抗菌剂投与), 抜歯 窝の上皮化の確認が必要と考えられた。

\section{結語}

BMT 予定患者 28 人に抜歯を行ない, 術後合併症に ついて検討した，その結果ドライソケット，後出血， 発熱が高頻度に出現し, 治癒期間の確保と術後管理の 重要性を認識した。

\section{引用 文 献}

1) Raber-Durlacher, J.E., Abraham-Inpijin, L., et al.: The prevention of oral complications in bone marrow transplantations by means of oral hygiene and dental intervention. Neth J Med 34: 98-108 1989.

2) Cutler, L.S.: Evaluation and Management of the Dental Patient with Cancer 1: Complications Associated with Chemotherapy or Bone Marrow Transplantation. J Conn State Dent Assoc 61: 236-238 1987.

3) Maxymiw, W.G. and Wood, R.E.: The role of dentistry in patients undergoing bone marrow transplantation. Br Dent $J$ 167: 229-234 1989.

4）大橋 靖, 加藤譲治, 他 : 抜歯の臨床 歯界展望 別冊, 医菌薬出版, 東京, 1979, 397-401 頁. 